\title{
Contemporary Aspects of Burn Care
}

\author{
Arij El Khatib ${ }^{1, *}$ and Marc G. Jeschke ${ }^{2}$ (D) \\ 1 Unité des Grands Brûlés, University of Montreal Medical Centre Sanguinet, 1051, Rue Sanguinet, \\ Montréal, QC H2X 0C1, Canada \\ 2 Department of Surgery, Division of Plastic Surgery, Department of Immunology, Ross Tilley Burn \\ Centre-Sunnybrook Health Sciences Centre, Sunnybrook Research Institute, University of Toronto, \\ 2075 Bayview Avenue, Rm D704, Toronto, ON M4N 3M5, Canada; marc.jeschke@sunnybrook.ca \\ * Correspondence: arijabdulhadi@gmail.com
}

\section{check for} updates

Citation: El Khatib, A.; Jeschke, M.G. Contemporary Aspects of Burn Care. Medicina 2021, 57, 386. https:/ / doi.org/10.3390/medicina57040386

Academic Editor: Lars P. Kamolz

Received: 8 March 2021

Accepted: 15 April 2021

Published: 16 April 2021

Publisher's Note: MDPI stays neutral with regard to jurisdictional claims in published maps and institutional affiliations.

Copyright: (c) 2021 by the authors. Licensee MDPI, Basel, Switzerland. This article is an open access article distributed under the terms and conditions of the Creative Commons Attribution (CC BY) license (https:// creativecommons.org/licenses/by/ $4.0 /)$.

\begin{abstract}
The past one hundred years have seen tremendous improvements in burn care, allowing for decreased morbidity and mortality of this pathology. The more prominent advancements occurred in the period spanning 1930-1980; notably burn resuscitation, early tangential excision, and use of topical antibiotic dressings; and are well documented in burn literature. This article explores the advancements of the past 40 years and the areas of burn management that are presently topics of active discussion and research.
\end{abstract}

Keywords: burn history; burn advancement; burn research

\section{Introduction}

Attempts to treat burn injury are as old as man's use of fire. The first depictions of burn injury and treatment have been found in cave drawings [1]. Documentation of treatment recommendations were found in ancient Egyptian writings, the Ebers and Smith papyri, dating over $1500 \mathrm{BC}$ (Before Christ), describing several treatment options including incantations, breast milk, and topical applications of multiple agents including honey, resin, and fabric strips soaked in oil as dressings [1-4]. Chinese medicine in the 6th century BC advocated the use of tea leaf extract on burns [2,3], while Hippocrates in the 4th century BC advocated multiple treatment options for burns including pig fat-soaked dressings, vinegar-soaked dressings, and balms made of oak bark [1-3]. Roman writings in the first century AD (Anno Domini) by Celsus also suggest different topical agents including honey, vinegar, bran, and exposure to air [2,3]. Arabian physicians used ice-cold water as advocated by Rhazes in the ninth century AC [2].

In the 16th century, Ambrose Pare advocated deep burn excision [4]. The first documented classification of burns was coined by Guilhelmus Fabricus Hildanus in the 17th century and was revisited multiple times by different authors including Richter and Dupuytren [3]. The three-degree classification most often used nowadays was coined separately by Petit in 1812 and Boyer in 1814 [3,5]. Reverdin recognized the importance of skin grafting in excised burn wounds, the standard treatment used for most deep burns today, in the 19th century [4]. Scotland is credited with starting the practice of treating burn patients in specialized burn units, with Syme establishing the first burn unit in Edinburgh in 1843 [6].

The 20th century saw a major leap in burn care and major improvements in patient survival. Forty-percent total body surface area burns in adults carried a 50\% mortality in the post-World War II era, while in the 1990s, 50\% mortality occurred in patients with burns of $80 \%$ of total body surface area [4]. This is due to numerous advancements that took place in both burn care, notably burn resuscitation and early excision; and non-burn specific advancements such as discovery of antibiotics and the tremendous improvements in intensive care therapy. 
In 1930, Underhill published an article reporting the need for fluid resuscitation in major burn patients after studying blister fluid in patients of the Rialto fire of 1921 [7]. These observations generated further research that culminated in fluid resuscitation formulae utilized to estimate appropriate volume of intravenous fluids to be given to specific body surface area burns. The first resuscitation formula based on body surface area was suggested by Harkins in 1942. Cope and Moore, studying the burn victims of the infamous Coconut Grove Fire in 1942, published their formula based on both extent of burn and patient weight [8]. Other authors followed suit proposing and modifying multiple formulae; culminating in the introduction the formula most widely used nowadays, the Parkland formula, described by Baxter and Shires in 1968 [9].

The World Wars, with unprecedented air warfare that resulted in mass burns contributed to development of burn reconstructive surgery, as these patients were treated in dedicated wards that developed the expertise of the treatment teams. Sir Archibald McIndoe was a pioneer in the field of burn reconstruction for his work on severely burned World War II pilots in the UK $[10,11]$.

Penicillin was discovered in 1929 by Alexander Fleming, but first documented antibiotic use in burn patients was first in the 1940s [12]. Antibiotic therapy, both topical and systemic, became a staple of burn treatment in the 1960s after publication of a series of papers on pseudomonal burn wound sepsis by Mason and Walker, and the reduction of postburn mortality by Pruitt et al. after use of mafenide acetate cream on burns in the 1960s [13-16].

While the tenets of burn surgery, namely the need for deep burn excision, remained the same as described centuries prior; the 20th century saw a paradigm shift to favor early excision as opposed to the earlier recommendations to wait until eschar separation $[17,18]$. The technique of tangential excision, popularized by Janzekovic in the 1970s, along with improvement in supportive care, made it possible to acutely excise large burns, resulting in decreases in mortality and length of hospital stay [3,18-25].

Most accounts of burn history deal with events up to the consolidation of the method of tangential early excision. Bridging the narrative to contemporary times, this article will discuss the major concepts, developments, and concerns of burn care of the last 40 years. Namely, these are (1) the research on and understanding of hypermetabolism as the pathophysiologic mechanism underlying the corporal response to major burns, (2) description of over-resuscitation for major burns, (3) the continuing battle with burn wound sepsis, (4) tissue bioengineering endeavors to produce an ideal skin substitute, and (5) use of lasers for modulation of burn scars (6) emphasis on mental health (7) rehabilitation, and (8) study of long-term outcomes of burn care.

\section{Hypermetabolism}

It has long been known that major burns are far from local events, having effects on multiple organ systems and lasting for long periods of time; however, the exact mechanisms of these phenomena have not been well understood. Originally described in the 1930s and supported by studies performed in the 1940s and 50s, the concept of hypermetabolism as the systemic response to burn injury has come into the center-stage of the understanding of burn injury within the last two decades, with intense research on its molecular basis and possible treatments [26-32]. Hypermetabolism is described as a conglomeration of cellular phenomena occurring in response to major trauma, caused by complex hormonal and inflammatory interplays and consisting of changes in glucose, protein, and fat metabolism [27,33-36].

Burn injury initially causes an 'ebb phase' of metabolism characterized by decreased organ function and tissue perfusion which lasts 1-3 days [26]. This is followed by the 'flow phase' which consists of increased inflammatory cytokine secretion, increased tissue perfusion, heightened adrenergic and glucocorticoid responses, and decreased levels of growth hormone [37]. This stage may last up to 2 years after the burn, and as can be inferred, results in increased oxygen and energy expenditure, and caloric requirement [26]. 
While the evolutionary role of hypermetabolism is to provide the body with substrates to regenerate and fight off insults, it has been recognized that the severity and longevity of this response in burn injury surpasses the bodily needs, becomes deleterious and is in itself a cause of significant morbidity and possibly mortality in burn patients. Glycolysis, proteolysis and lipolysis cause significant catabolism, loss of lean body mass, physiologic exhaustion, delays in wound healing, and immune system dysfunction [37-40].

Traditionally, the two ways of off-setting hypermetabolism in major burn patients is to surgically excise the burn, thereby removing the major source of inflammation; and to provide the patient with adequate nutrition to limit lean body mass wasting and further catabolism $[27,39,41]$.

The most powerful intervention that can be implemented in a major burn patient to curb hypermetabolism and decrease morbidity and mortality is undoubtedly early burn excision and closure of the resulting wounds [27,33]. Historically, this has become possible in the past 4 decades not because of advancement in surgical technique, as excision of burn wounds had been practiced for centuries; but because of advancements in supportive care allowing for the performance of safer surgery. The two fields allowing for this are intensive care which has provided the treatment of infections, blood transfusions, mechanical ventilation, blood pressure support, and enhanced patient monitoring; and the field of bioengineering that has provided skin substitutes allowing options for wound closure.

It is imperative to provide burn patients with adequate nutrition, currently, nutritional support is started enterally as early as possible, usually on the day of injury [27,42]. Nutritional requirements are calculated based on patients' resting energy expenditure; inadequate nutrition is associated with muscle wasting which in turn can lead to immune dysfunction, impaired wound healing, infections, and death; conversely, excess nutrition can lead to hyperglycemia and fatty infiltration of organs $[27,42,43]$. There is no consensus on the ideal nutrition for burn patients, and while research is actively being conducted to determine the optimal ratios of macro- and micronutrients, it is generally accepted that the majority of calories are to be obtained from carbohydrates with careful control of fatty acids to avoid organ infiltration and dysfunction. It is also standard practice to provide patients with micronutrients including Vitamins A, C, and E; as well as selenium, zinc, copper, and iron to offset oxidative stress, modulate immune function, and promote wound healing [44]. Studies on individual essential amino acids such as glutamine and alanine are also being carried out $[27,42,44]$.

While effective in attenuating the hypermetabolic response, burn excision and adequate nutrition do not completely halt it [26], resulting in attempts to mitigate it using pharmacological agents, including the following:

(a) Insulin: Hyperglycemia has been implicated in multiple detrimental processes in burn patients, including delayed wound healing, infections, and increased mortality. Conversely, keeping a burn patient's glucose controlled around the $130 \mathrm{mg} / \mathrm{dL}$ mark has been shown to decrease patient mortality and morbidity associated with sepsis and infections [37,45-48]. Insulin was one of the first agents studied to curb hypermetabolism by controlling hyperglycemia and overcoming insulin resistance that develops in hypermetabolic patients. Insulin has also been shown to downregulate inflammatory cytokines and contribute to improved wound healing [27,37]. A drawback of insulin therapy is that it necessitates rigorous blood glucose measurements to avoid hypoglycemia which may be serious, and potentially fatal in the intensive care setting $[37,45]$.

(b) Metformin: A possible replacement for insulin therapy that is currently being investigated for effectiveness of glucose control and hypermetabolism attenuation is Metformin. Its advantages are the easier dosing and less need for monitoring, as it does not cause hypoglycemia. Metformin may cause lactic acidosis however and renal failure in rare cases $[27,37,45]$.

(c) Propranolol: A non-specific b-adrenergic blocker, propranolol has been shown to decrease the hypermetabolic response due to its ability to block the sympathetic 
response, thereby decreasing cardiac workload, insulin resistance, and loss of lean body mass, among other beneficial effects $[27,49,50]$.

(d) Recombinant Human Growth Hormone (rHGH): rHGH has been studied as an agent for treatment of hypermetabolism due to the findings that its levels are low in hypermetabolic patients. While it has shown favorable outcomes in pediatric populations, including increase in lean body mass, it is seldom used in adults due to a study that citing high rates of mortality and morbidity in adults with the use of rHGH $[27,37,51]$.

(e) Oxandrolone: A synthetic testosterone analog that possesses only $5 \%$ of testos-terone's virilizing effects. Being an anabolic hormone, it helps in maintenance of lean body mass and has been shown to shorten hospital stay in burned children [32,52].

\section{Fluid Creep}

Fluid resuscitation is a cornerstone of burn treatment; its study and protocolization in the 20th century have led to significant increases in burn patient survival [4]. However, recognition of over-resuscitation, known as fluid creep, and its detrimental effects on patient course and outcomes have dominated the past 2 decades [53]. In 2000, Pruitt famously wrote about the pendulum of resuscitation swinging in the direction of overresuscitation of acute burns with crystalloid solution and emphasized the need to reverse this phenomenon [54].

There are recognized patient conditions that require higher-than-normal resuscitation volumes. These include very large total body surface area (TBSA) burns, inhalation injury, electrical injury, delayed presentation of burned patient, and polytrauma $[55,56]$. Recent literature suggests that routine burn patients without the previously mentioned conditions are increasingly receiving volumes of resuscitation fluid in excess of those advocated by resuscitation calculations [55-60]. Adverse effects of fluid creep include increased extremity pressures that may require release in the form of escharotomies or fasciotomies, airway edema potentially requiring intubation, and abdominal compartment syndrome [55-59,61].

While the exact mechanisms of fluid creep have not been delineated, it most probably is a multifactorial phenomenon caused by a combination of the following factors:

(a) Carelessness: patients receiving large volumes as runs by first responders, directly on admission, and reluctance of tapering of high volume infusions for fear of causing renal failure [55,60].

(b) Larger burns: the resuscitation formulae were described when burn survival in patients with very large burns was rare. Therefore, adequacy of the formulas is studied best in moderate-sized burns, whereas fluid requirements for large and very large burns may go beyond what can accurately be predicted by resuscitation formulas [9,55].

(c) Opioid creep: opioid analgesia, which is much more frequently used now than in the past, causes decreases in blood pressure which is then counteracted with larger resuscitation fluid volumes $[55,62]$.

(d) Goal-directed resuscitation: resuscitation to achieve certain urine outputs or basedeficit figures without regard for clinical fluid balances and edema. Studies suggest that certain goals such as base deficit require $24-48 \mathrm{~h}$ to normalize even in the setting of adequate resuscitation [55,63]. Interim readings before value normalization may however prompt over-resuscitation [57].

(e) Pure crystalloid: patients resuscitated with crystalloid solution only require higher fluid volumes than those resuscitated with colloid $[56,64]$. In fact, the earliest version of the Parkland formula included colloid addition in the second day of resuscitation $[55,56]$. Colloids fell out of favor due to a study by Goodwin et al. in 1983 that showed increased mortality in patients receiving albumin [65]. Newer studies fail to demonstrate increased mortality with the use of colloids but also do not demonstrate a survival benefit with their use [60,66-68]. 


\section{Sepsis in Burns}

Sepsis is described as organ damage in the context of a dysregulated systemic inflammatory response to an infectious agent [69]. It is a primary cause of mortality in intensive care units worldwide and is presently the leading cause of death in patients with severe burns [70]. Due to this, sepsis has been the topic of much recent study and discussion. Its definition and diagnostic criteria have been revised frequently in the past three decades, leading to some confusion about the interpretation of study results and the appropriateness of comparison of different therapeutic trials due to use of different defining parameters. The need for standardization of the definition of sepsis has been recognized as a step towards clarity in the clinical diagnosis and therapeutic results of the condition.

Traditionally, sepsis was defined as evidence of an infection in addition to a systemic inflammatory response syndrome (SIRS) [71]; whereas SIRS was defined as two or more of the following: temperature $>38^{\circ} \mathrm{C}$ or $<36^{\circ} \mathrm{C}$, heart rate $>90$ beats per minute, respiratory rate $>20$ breaths per minute or maintenance of $\mathrm{PaCO}_{2}<32 \mathrm{mmHg}$, or white bloodcount $>$ $12,000 / \mathrm{mm}^{3}$ or $4000 / \mathrm{mm}^{3}$ or left shift defined as $>10 \%$ bands [72].The latest widely agreedupon definition is the Sepsis-3 definition developed by the Third International Consensus Definitions for Sepsis and Septic Shock (Sepsis-3) in 2016 [73-75]. Sepsis-3 defines sepsis in terms of Sequential Organ Failure Assessment (SOFA) variables which are: $\mathrm{PaO}_{2} / \mathrm{FiO}_{2}$ ratio, Glasgow Coma Scale, mean arterial pressure, vasopressor requirements, serum creatinine or urine output, bilirubin, and platelet count; or quick SOFAs (qSOFAs) which are altered mental status (Glasgow Coma Scale GCS $<13$ ), systolic blood pressure $\leq 100 \mathrm{mmHg}$, and respiratory rate $\geq 22$ [73].SOFA and qSOFA variables are essentially proxies for organ dysfunction, and sepsis is defined as 2 or more SOFA criteria, or documented infection in addition to 2 or more qSOFA criteria [73-75].

Burn patients are habitually excluded from sepsis trials due to the overlap of traditional systemic inflammatory response syndrome (SIRS) symptoms such as tachycardia, tachypnea, fever, and leukocytosis with the inflammatory and hypermetabolic reactions seen in response to major burn injury $[71,76,77]$; therefore, sepsis definitions used in the general patient population are not validated in the burn patient population $[71,78,79]$. The American Burn Association (ABA) has developed a burn-specific definition of sepsis in 2007 in response to this dilemma, with the following criteria: temperature $>39^{\circ} \mathrm{C}$ or $<36.5^{\circ} \mathrm{C}$, progressive tachycardia $>110$ beats per minute, progressive tachypnea $>25$ breaths per minute, thrombocytopenia $<100,000 / \mathrm{mcL}$, hyperglycemia in the absence of pre-existing diabetes mellitus, inability to continue enteral feedings $>24 \mathrm{~h}$ [76]. In addition, the ABA definition requires that a documented infection is identified by a positive culture, or pathologic tissue source, or clinical response to antimicrobials [76]. Several trials have compared the Sepsis-3 and ABA criteria for predicting sepsis in the burn population and found Sepsis-3 to be superior to the ABA criteria [78]. It must be noted that Sepsis-3 definition has come under scrutiny for not being sufficiently specific for sepsis in burn patients [80]. Therefore, the pursuit for a satisfactory definition of sepsis in burn patients is still ongoing.

Major burn patients differ from the general patient population in terms of sepsis in that they present with loss of the body's skin barrier function, which predisposes them to sepsis for prolonged periods of time; this is exacerbated by the immune compromise that is frequently observed in the context of major burns [71]. Additionally, major burn patients often require mechanical ventilation, central venous, arterial, and urinary catheterization, all of which further increase infection risk. As a result, rigorous infection prevention and control measures are the norm in modern burn units in an attempt to reduce the likelihood of infection. These measures include screening for resistant organisms upon admission and discharge of patients, individual patient rooms, contact isolation measures, a strong emphasis on hygiene, daily antimicrobial dressings for burn wounds, monitoring of need and status of all invasive catheters, and careful antimicrobial stewardship [70].

Effort has been put into collecting and protocolizing evidence on sepsis management, with the result being the Surviving Sepsis Campaign (SSC) guidelines that have been devel- 
oped and published periodically since 2004. These guidelines are presented as collections of treatment recommendations, or 'bundles', that should be implemented within specific time frames or in response to certain signs and symptoms [81-83]. Adherence to these 'bundle' interventions has shown a decrease in mortality rates of sepsis in the general population [69]. While the management recommendations indicated in the Surviving Sepsis Campaign are mostly not new, consisting notably of intravenous fluid resuscitation, administration of antimicrobial agents after taking cultures, vasopressor support to maintain a (mean arterial pressure) MAP $\geq 65$, renal replacement, and glycemic control [83]. It is the timeliness of these interventions that is an important predictor of survival in sepsis, with evidence of increase in mortality for each hour antimicrobial therapy is delayed after the onset of hypotension [84].

Most of the criteria included in any definition of sepsis are clinical. The few laboratory measurements included (platelet count, bilirubin) are non-specific. The development of a sepsis-specific laboratory marker could greatly help in the prompt diagnosis and follow-up of sepsis, especially in major burn patients, where most of the clinical signs and symptoms are common to both conditions and it is difficult to distinguish etiology. Currently, the two markers used as measures of sepsis are C-reactive protein (CRP) and Procalcitonin. While CRP is sensitive for inflammation, it is less specific for infection and is slower to change, with the half-life of several days [85]. The more expensive Procalcitonin is more specific to infection and has a shorter half-life and may therefore be useful as a marker of change in condition. Although it has been shown to be a relatively good marker for sepsis and survival in burn patients, its levels are subject to fluctuations in response to surgery and different types of microbial agents, making interpretations more complicated [77,86-90].

\section{Skin Substitutes}

Autograft donor sites in the body are limited. This limitation is compounded by the need for wound coverage after early excision, especially in the case of large burns [91]. One solution for this is the use of skin substitutes, which are naturally-occurring or manufactured alternatives to autografts that can be either temporary or permanent and replace the epidermis, the dermis, or both [17,92]. Ideally, a skin substitute should provide wound coverage to limit fluid loss and bacterial growth, reduce pain and allow for wound healing. There is no perfect skin substitute; the past 4 decades saw a boom of biotechnology in an attempt to make an ideal skin replacement. The following is a limited list of skin substitutes used in burn units today.

The earliest skin substitutes used were allografts, or cadaveric skin, first used by Girdner in 1881 [93,94]. Most major burn centers use allografts as a wound bed preparation material in moderate to large burns, to increase the likelihood of subsequent autograft take [93]. The drawbacks of allograft use are the need for resources (skin banks) for its storage, as well as its antigenicity which usually manifests at around 3 weeks after its application, necessitating its replacement with autograft.

One solution to the antigenicity and impermanence of allografts, while avoiding the morbidity and scarcity of traditional autografts is to culture skin from a small skin sample taken from the burn patient. Cultured keratinocytes, or cultured epithelial autografts (CEA), were first reported in 1981 by $\mathrm{O}^{\prime}$ Connor et al. and required 3-5 weeks for the growth in vitro of sheets of epithelial cells from a small biopsy of a patient's normal skin [17,95-97]. Advantages are lack of immunogenicity and negligible donor sites, disadvantages are fragility of the sheets (due to lack of dermal component which is what gives skin its elasticity and strength), high cost, and time for production [95,98-100]. CEA has evolved from culturing cells in sheets which may take up to 5 weeks, to culturing cells in suspension which takes 2-3 weeks $[95,97]$. Currently, several systems of suspended keratinocyte delivery are available in the market, these are usually applied over a dermal substitute in order to achieve some elasticity and strength $[95,97]$.

Multiple attempts have also been made at producing a skin substitute that would simultaneously replace the epidermal and dermal layers, with the goal of achieving a 
skin substitute that is stronger, more elastic, and more resistant to wear than a cultured keratinocyte sheet. One such substitute is the self-assembled skin substitute (SASS) that is composed of a collagen-rich extracellular matrix produced by a patient's fibroblasts which is then seeded with keratinocytes thereby producing a substitute that is non-immunogenic and contains both skin layers [91,98]. Limitations include the time needed for production and high cost.

Numerous non-human tissue skin substitutes have also been developed for use in the burn patient to replace the various skin components. While an exhaustive list of synthetic substitutes is beyond the scope of this text, three substitutes that are prevalent in modern burn units and warrant mention are Biobrane ${ }^{\circledR}$, Integra ${ }^{\circledR}$, and BTM ${ }^{\circledR}$.

Biobrane ${ }^{\circledR}$ is an epidermal substitute that is a synthetic bilayer consisting of an inner nylon mesh and an outer silastic membrane. It is most commonly applied to superficial second degree burns to act as a semi-occlusive dressing, thereby diminishing fluid loss and decreasing pain associated with dressing changes while the superficial burn heals spontaneously [101,102]. It has been particularly useful in pediatric patients with superficial second degree burns, but has also found uses in patients with non-burn epithelial defects such as toxic epidermal necrolysis syndrome (TENS) [103].

Integra ${ }^{\circledR}$ is a dermal regeneration template developed in the 1970 s by Yannis and Burke. It consists of a chondroitin-collagen dermis covered by a silastic epidermis [3,4]. The dermal matrix allows for migration of fibroblasts and macrophages and becomes vascularized and incorporated into the body, and the silastic epidermis is removed and autografted 3 weeks after application. Integra carries the advantage of easy storage and decreased contracture compared to autograft only [104,105], and of being able to survive on small exposed areas of bone or tendon, on which autograft alone does not survive. Disadvantages include infections and its high cost $[17,105]$. Biodegradable Temporizing Matrix, or BTM ${ }^{\circledR}$, is a synthetic polyurethane dermal substitute developed in 2012 by Greenwood that incorporates into the body through ingrowth of blood vessels and fibroblast infiltration $[106,107]$. Like Integra ${ }^{\circledR}$, it contains a sealing membrane that is removed 3-4 weeks after application, allowing the dermal matrix to be skin grafted [17,99]. Preliminary data show decreased contracture rates and decreased infections $[99,100]$.

\section{Lasers}

Burn scars are a well-recognized sequela of major burn injury. In addition to unsightly appearance, these can limit function through contracture formation, and cause neuropathic pain, itching, and repetitive wound breakdown [108-113]. Increased burn patient survival has meant an increased burden of burn scar morbidity and has brought the need for effective scar therapies to the forefront of burn care.

Traditionally, burn scar treatment has included conservative modalities such as compression garments, applications of intralesional steroids, silicone creams; and surgical modalities such as scar release or excision and grafting [108-113]. Laser therapy has emerged as a novel technique of manipulating scar tissue in the past 20 years [114].

Lasers can be classified as non-ablative and ablative, the difference being their mode of action. Non-ablative lasers target pigments within the skin, and may be used for hyperpigmentation, vascular anomalies and tattoo removal; while ablative lasers vaporize tissues, modulating scar tissue [111].

Pulse-dye lasers are an example of non-ablative lasers, they have a wavelength of $585 \mathrm{~nm}$ or $595 \mathrm{~nm}$ and target oxygenated hemoglobin within capillaries in the dermis causing the coagulation of these vessels resulting in decreased erythema in the scar [110,111,115-118]. Erbium-yttrium aluminium garnet (Erbium-YAG and CO2 lasers are examples of ablative lasers, they target abnormal collagen, destroying it and promoting formation of new collagen, consequently remodeling scar tissue [110,111,115-118]. Erbium-YAG has a wavelength of $2490 \mathrm{~nm}$ enabling it to target dermal matrix components, while the $\mathrm{CO}_{2}$ laser has a wavelength of $10,600 \mathrm{~nm}$ and is therefore able to effectuate more extensive tissue remodeling due to its ability to vaporize scar tissue and coagulate blood 
vessels in the scar at the same time. This higher energy however, also carries the potential for more complications due to the higher energy dispersal. Complications of laser therapy include erythema, swelling, pain, skin infection, and hyperpigmentation [110,111,115-118].

Extension of previous laser indications include laser therapy prior to definitive reconstructive surgery for contractures in an attempt to soften scar tissue, making it more malleable; as well as the topical application of corticosteroids just prior to laser therapy, the belief being that laser beams will allow enhanced delivery of the steroids into the scar $[110,117,119]$.

\section{Mental Health}

The first time mental health was acknowledged as a major component of burn patient recovery was in the work of McIndoe on his patients who were mostly WWII soldiers [120]. The Guinea Pig Club was formed by his patients in 1941 to provide burn reconstruction patients with social and psychological support. Research done in the late 1980s and 1990s demonstrated that up to $45 \%$ of adult patients hospitalized for burn injury showed signs of post-traumatic stress disorder 1 year after their initial injury [121]. It has also been demonstrated that prevalence rates of psychological distress and anxiety are high in hospitalized patients and that these symptoms tend to persist after discharge [122]. Compounding the problem of psychiatric issues in burn patients is the high incidence of pre-existing psychiatric conditions, alcoholism, and substance abuse [123-126], which in some cases may be the inciting agents of the burn [127]. Patients with pre-existing psychiatric conditions have been found to have higher rates of complications and require longer hospitalizations after a burn injury, as well as more difficulties in rehabilitation and readjustment postburn [128-132]. Acute stress disorder starts immediately after hospitalization and if left untreated may be a predictor of future post traumatic stress disorder (PTSD) [127,133].The burn team needs to be attuned to the patient's psychological wellbeing and symptoms of stress, depression, anxiety, and sleep disturbance must be promptly recognized and treated. Mental health professionals such as counselors, psychologists and psychiatrists are an integral part of any burn unit.

Pain is strongly linked with stress, anxiety, and sleep disorders in burn patients; inversely, patients with these psychological symptoms also become less tolerant to pain and may even have decreased wound healing [134,135]. Pain is a strong predictor of both acute and long-term psychological sequelae, and both pain and psychiatric disorders are strong predictors of long-term functioning in burn patients [123,136-139]. Anxiety and depression caused by excessive pain are decreased with adequate pain management [135].

Pain management is of paramount importance to burn care. The ABA has published guidelines for the management of acute pain and the recommendations include the need for frequent burn assessments, pharmacological therapy that includes opioids as well as adjuncts such as acetaminophen and non-steroidal anti-inflammatory drugs (NSAIDs), agents for neurologic pain such as gabapentin and pregabalin, and the use of ketamine for procedural sedation when needed (by trained personnel) [140]. The guidelines also include the recommendation to offer patients nonpharmacological analgesia techniques, such as cognitive behavioral therapy, hypnosis and virtual reality (VR) when available. Hypnosis has been found to significantly reduce affective pain in burn patients as well as flashbacks to the inciting incident [141-144]. There is significant evidence for the use of virtual reality as a nonpharmacological analgesic technique, it has been found to decrease both pain and anxiety associated with dressing changes, procedures, and physiotherapy and is a powerful analgesic adjunct to pharmacological therapy [121,145-152]. Functional magnetic resonance imagine (MRI) imaging has shown decreased pain-related brain activity with the use of VR [153].

Burn patients need to reintegrate back into their lives and communities after discharge from the burn unit, this is a process that goes hand in hand with physical rehabilitation and may require education of the patients and their families as well as social support. Much in the same tradition of the Guinea Pig Club, burn survivor groups provide an understanding 
and supportive social network that can assist patients in their recovery $[154,155]$. Variables affecting success of reintegration include physical impairment, pre- and postburn psychological distress, and substance abuse, among others [122]. About $66 \%$ of adult patients are found to be working 2 years after their major burns [156], and presence of work correlates with a better subjective quality of life $[157,158]$.

Followup of children who survive major burns reveals that most of them adapt satisfactorily [159]. In adolescents and young adults, 40-50\% were found to be welladjusted, $50-60 \%$ were found to have some degree of psychological distress, and $25 \%$ were found to have severe symptoms. In fact, the most debilitating long-term effects of childhood burns are psychological and not physical [160]. Social skills programs have been shown to improve psychosocial competence of adolescent burn survivors [159-162].

\section{Rehabilitation}

Burn treatment does not end with wound coverage or hospital discharge. Rehabilitation is an integral part of burn care, and probably the stage of burn management that lasts the longest. Burn injuries are notorious for function-limiting sequelae, including contractures, hypertrophic scarring, amputations, pruritus, thermoregulatory anomalies, hyperesthesias and paresthesias.

Rehabilitation has come to play a central role in burn management as survival of burn patients has improved, and quality of life and level of function of patients became the focus of recovery. It nowadays starts in the acute phase just after admission and carries on after patient discharge, and comprises of a vast variety of treatments including physiotherapy, ergotherapy, pain management, pressure garments, masks for hypertrophic scarring, and prosthetics $[113,163]$.

The earliest rehabilitation intervention implemented after patient admission to the burn unit is positioning. The patient as well as the burned body part should be held in a position of comfort that nonetheless minimizes the chances of wound and joint contractures, edema, and pressure injury $[164,165]$. The strategies used for positioning may include techniques such as splinting, orthoses, special mattresses, foam cushions/wedges, and pressure dressings [165]. The particular strategies used are highly individualized and should be frequently reassessed and modified as the need arises.

The intermediate phase of rehabilitation spans the period of wound healing; priorities at this time are stretching of healing skin, grafts, and joints to prevent contractures and keep the tissues supple $[166,167]$. Long-term burn rehabilitation occurs after discharge and continues until the patient has gleaned the maximal benefit possible [166]. Rehabilitation programs range from inpatient to outpatient with frequent follow-ups, to patients becoming able to independently effectuate their programs with minimal oversight. The goals of longterm rehabilitation is to achieve maximal range of motion and functionality, and to learn to compensate for function that cannot be restored.

An important aspect of rehabilitation is scar management. Facial masks used to attenuate hypertrophic scarring of facial burns, as well as pressure garments used for scars for other body areas usually fall under the supervision of the burn physiotherapist. Evidence on the efficacy of pressure garments is not indisputable, with multiple studies falling on either side of the debate. The use of pressure to modulate scar healing was first mentioned in the medical literature in the late 1800s and was popularized in the 1970s; the supporters of garment use cite studies showing that application of pressure to a raised scar reduced its thickness and helped in its maturation [168-174]. The detractors argue that the garments do not apply adequate pressure, need to be worn for $23 \mathrm{~h}$ a day which is difficult to comply with; and that they cause discomfort, skin breakdown, and limitation of motion [175-178].

\section{Long-Term Outcomes}

Outcomes of burn care had historically been measured in terms of survival or length of stay. As survival rates of major burns increase, longer-term outcomes such as quality 
of life, psychosocial well-being, and return to work, may provide greater insights into the consequences of major burns. This in turn allows for patient-centric care and anticipation of patient needs not only in the immediate aftermath of a major burn, but also in the longrun [179-181]. Collection of long-term prospective data on multiple aspects of patient care and its results with respect to patient functioning, as well as periodic review of this data and identification of areas for improvement is a hallmark of major burn units. Verification by the American Burn Association stipulates that every verified burn unit collect data on burn admissions and their complications and outcomes, and creates a framework for collaboration of different burn units and teams on research.

\section{Conclusions}

Despite the impressive evolution that has taken place in burn care over the past century, there is ample room for further growth. The future will entail developments in the avenues discussed above. Dedicated efforts are being made in order to achieve better understanding and control of hypermetabolism, with ongoing trials on pharmacological agents to modulate the hypermetabolic response; glutamine and combination antihyperglycemics are currently being studied [27]. Research is also ongoing for biomarkers of hypermetabolism, with the goal of discovering markers that are easy to test for and that provide information on response to treatment and prognosis [27,182].

Likewise, optimal ways to resuscitate major burn patients with minimal side effects is an ongoing field of study, one notable trial that is currently in progress is the Acute Burn ResUscitation Multicenter Prospective Trial (ABRUPT2), evaluating acute resuscitation of major burns with crystalloid alone versus crystalloid with the addition of $5 \%$ albumin at 8 $h$ post burn [183].

In the field of sepsis, active areas of investigation are the testing of sensitive and specific biomarkers of sepsis, with research into leukocyte biomarkers which may replace the currently used CRP and Procalcitonin measurements [184]. Another important field in sepsis research is the development of techniques that allow the detection of bacterial or fungal DNA within the bloodstream within hours, precluding the need to wait for days for antimicrobial culture results [85]. In addition, investigations on ways to develop therapeutic agents/biotechnology to allow the removal of inflammatory factors and cytokines from the bloodstream, therefore curbing the dysregulated reaction to infection in septic patients is underway [85].

Mesenchymal stem cells (MSCs) have been found to enhance wound healing capabilities $[185,186]$. It has also been discovered that burnt tissue that is excised in the process of burn debridement contains active MSCs. Research is ongoing on extracting these MSCs from burnt tissue, and incorporating them into a 3D-printed skin substitute that will not use healthy skin as a donor, and will not be immunogenic as the MSCs will come from a patient's own burnt, discarded tissue $[187,188]$. If successful, this may prove revolutionary as a skin substitute option.

Evaluation and refinement of laser techniques and study of scar modulation techniques are also active areas of research, as are mental health interventions, and burn rehabilitation techniques. In the light of the better understanding of the pathophysiology and treatment of burns and the active research being conducted on many aspects of burn care, the future holds hope of improving outcomes and alleviating the suffering of burn patients.

Author Contributions: A.E.K.: Conceptualization, writing original draft, review and editing. M.G.J.: Supervision, data curation, and editing. All authors have read and agreed to the published version of the manuscript.

Funding: This research received no external funding.

Institutional Review Board Statement: Not Applicable.

Informed Consent Statement: Not Applicable. 
Data Availability Statement: Data sharing not applicable.

Conflicts of Interest: The authors declare no conflict of interest.

\section{References}

1. Hussain, A.; Choukairi, F. To cool or not to cool: Evolution of the treatment of burns in the 18th century. Int. J. Surg. 2013, 11, 503-506. [CrossRef]

2. Artz, C.P. Historical Aspects of Burn Management. Surg. Clin. N. Am. 1970, 50, 1193-1200. [CrossRef]

3. Moiemen, N.S.; Lee, K.C.; Joory, K. History of burns: The past, present and the future. Burn. Trauma 2014, 2, 169-180. [CrossRef]

4. Liu, H.-F.; Zhang, F.; Lineaweaver, W.C. History and Advancement of Burn Treatments. Ann. Plast. Surg. 2017, 78, S2-S8. [CrossRef] [PubMed]

5. $\quad$ Denkler, K. History of burns. Plast. Reconstr. Surg. 1999, 104, 308-309. [CrossRef]

6. Wallace, A.F. Recent advances in the treatment of burns-1843-1858. Br. J. Plast. Surg. 1987, 40, 193-200. [CrossRef]

7. Underhill, F.P. The significance of anhydremia in extensive superficial burns. JAMA 1930, 95, 852-857. [CrossRef]

8. Alvarado, R.; Chung, K.K.; Cancio, L.C.; Wolf, S.E. Burn resuscitation. Burns J. Int. Soc. Burn Inj. 2009, 35, 4-14. [CrossRef]

9. Baxter, C.R.; Shires, T. Physiological response to crystalloid resuscitation of severe burns. Ann. N. Y. Acad. Sci. 1968, 150, 874-894. [CrossRef] [PubMed]

10. Mayhew, E.R. The Guinea Pig Club: Archibald McIndoe and the RAF in World War II; Dundurn Press: Toronto, ON, Canada, 2018.

11. McIndoe, S.A. Total Facial Reconstruction Following Burns. Postgrad. Med. 1949, 6, 187-200. [CrossRef]

12. Lyons, C. Penicillin therapy of surgical infections in the U. S. ARMY. J. Am. Med Assoc. 1943, 123, 1007. [CrossRef]

13. Teplitz, C.; Davis, D.; Mason, A.D.; Moncrief, J.A. Pseudomonas burn wound sepsis. I Pathogenesis of experimental pseudomonas burn wound sepsis. J. Surg. Res. 1964, 4, 200-216. [CrossRef]

14. Teplitz, C.; Davis, D.; Walker, H.L.; Raulston, G.L.; Mason, A.D.; A Moncrief, J. Pseudomonas burn wound sepsis. II Hematogenous infection at the junction of the burn wound and the unburned hypodermis. J. Surg. Res. 1964, 4, 217-222. [CrossRef]

15. Walker, H.L.; Mason, A.D.; Raulston, L.C.G.L. Surface Infection with Pseudomonas Aeruginosa. Ann. Surg. 1964, 160, $297-305$. [CrossRef]

16. Pruitt, B.A.; O’Neill, J.A.; Moncrief, J.A.; Lindberg, R.B. Successful Control of Burn-Wound Sepsis. JAMA 1968, 203, 1054-1056. [CrossRef]

17. Kearney, L.; Francis, E.C.; Clover, A.J. New technologies in global burn care-A review of recent advances. Int. J. Burn. Trauma 2018, 8, 77-87.

18. Herndon, D.N.; Barrow, R.E.; Rutan, R.L.; Rutan, T.C.; Desai, M.H.; Abston, S. A Comparison of Conservative versus Early Excision. Ann. Surg. 1989, 209, 547-553. [CrossRef]

19. Barret, J.P.; Herndon, D.N. Effects of Burn Wound Excision on Bacterial Colonization and Invasion. Plast. Reconstr. Surg. 2003, 111, 744-750. [CrossRef] [PubMed]

20. Thompson, P.; Herndon, D.N.; Abston, S.; Rutan, T. Effect of Early Excision on Patients with Major Thermal Injury. J. Trauma Inj. Infect. Crit. Care 1987, 27, 205-207. [CrossRef] [PubMed]

21. Janžekovič, Z. A new concept in the early excision and immediate grafting of burns. J. Trauma Inj. Infect. Crit. Care 1970, 10, 1103-1108. [CrossRef]

22. Tompkins, R.G.; Remensnyder, J.P.; Burke, J.F.; Tompkins, D.M.; Hilton, J.F.; Schoenfeld, D.A.; Behringer, G.E.; Bondoc, C.C.; Briggs, S.E.; Quinby, W.C. Significant Reductions in Mortality for Children With Burn Injuries Through the Use of Prompt Eschar Excision. Ann. Surg. 1988, 208, 577-585. [CrossRef] [PubMed]

23. Pietsch, J.B.; Netscher, D.T.; Nagaraj, H.S.; Groff, D.B. Early excision of major burns in children: Effect on morbidity and mortality. J. Pediatr. Surg. 1985, 20, 754-757. [CrossRef]

24. Janzekovic, Z. Once upon a time. How west discovered east. J. Plast. Reconstr. Aesthetic Surg. 2008, 61, 240-244. [CrossRef]

25. Engrav, L.H.; Heimbach, D.M.; Reus, J.L.; Harnar, T.J.; Marvin, J.A. Early excision and grafting vs. nonoperative treatment of burns of indeterminant depth: A randomized prospective study. J. Trauma 1983, 23, 1001-1004. [CrossRef] [PubMed]

26. Sommerhalder, C.; Blears, E.; Murton, A.J.; Porter, C.; Finnerty, C.; Herndon, D.N. Current problems in burn hypermetabolism. Curr. Probl. Surg. 2020, 57, 100709. [CrossRef] [PubMed]

27. Jeschke, M.G. Postburn Hypermetabolism: Past, Present, and Future. J. Burn Care Res. 2016, 37, 86-96. [CrossRef] [PubMed]

28. Wilmore, D.W. Hormonal Responses and Their Effect on Metabolism. Surg. Clin. N. Am. 1976, 56, 999-1018. [CrossRef]

29. Wilmore, D.W.; Long, J.M.; Mason, A.D.; Skreen, R.W.; Pruitt, B.A. Catecholamines: Mediator of the hypermetabolic response to thermal injury. Ann. Surg. 1974, 180, 653-669. [CrossRef]

30. Wolfe, R.R.; Herndon, D.N.; Jahoor, F.; Miyoshi, H.; Wolfe, M. Effect of Severe Burn Injury on Substrate Cycling by Glucose and Fatty Acids. N. Engl. J. Med. 1987, 317, 403-408. [CrossRef]

31. Wolfe, R.R.; Herndon, D.N.; Peters, E.J.; Jahoor, F.; Desai, M.H.; Holland, O.B. Regulation of Lipolysis in Severely Burned Children. Ann. Surg. 1987, 206, 214-221. [CrossRef]

32. Hart, D.W.; Wolf, S.E.; Ramzy, P.I.; Chinkes, D.L.; Beauford, R.B.; Ferrando, A.A.; Wolfe, R.R.; Herndon, D.N. Anabolic Effects of Oxandrolone After Severe Burn. Ann. Surg. 2001, 233, 556-564. [CrossRef]

33. Herndon, D.N.; Tompkins, R.G. Support of the metabolic response to burn injury. Lancet 2004, 363, 1895-1902. [CrossRef] 
34. Jeschke, M.G.; Chinkes, D.L.; Finnerty, C.C.; Kulp, G.; Suman, O.E.; Norbury, W.B.; Branski, L.K.; Gauglitz, G.G.; Mlcak, R.P.; Herndon, D.N. Pathophysiologic Response to Severe Burn Injury. Ann. Surg. 2008, 248, 387-401. [CrossRef] [PubMed]

35. Jeschke, M.G.; Gauglitz, G.G.; Kulp, G.A.; Finnerty, C.C.; Williams, F.N.; Kraft, R.; Suman, O.E.; Mlcak, R.P.; Herndon, D.N. Long-Term Persistance of the Pathophysiologic Response to Severe Burn Injury. PLoS ONE 2011, 6, e21245. [CrossRef]

36. McCowen, K.C.; Malhotra, A.; Bistrian, B.R. Stress-Induced Hyperglycemia. Crit. Care Clin. 2001, 17, 107-124. [CrossRef]

37. Auger, C.; Samadi, O.; Jeschke, M.G. The biochemical alterations underlying post-burn hypermetabolism. Biochim. Biophys. Acta (BBA) Mol. Basis Dis. 2017, 1863, 2633-2644. [CrossRef]

38. Hart, D.W.; Wolf, S.E.; Chinkes, D.L.; Gore, D.C.; Mlcak, R.P.; Beauford, R.B.; Obeng, M.K.; Lal, S.; Gold, W.F.; Wolfe, R.R.; et al. Determinants of Skeletal Muscle Catabolism After Severe Burn. Ann. Surg. 2000, 232, 455-465. [CrossRef] [PubMed]

39. Orgill, D.P. Excision and Skin Grafting of Thermal Burns. N. Engl. J. Med. 2009, 360, 893-901. [CrossRef] [PubMed]

40. Porter, C.; Tompkins, R.G.; Finnerty, C.C.; Sidossis, L.S.; E Suman, O.; Herndon, D.N. The metabolic stress response to burn trauma: Current understanding and therapies. Lancet 2016, 388, 1417-1426. [CrossRef]

41. Gore, D.C.; Chinkes, D.; Sanford, A.; Hart, D.W.; Wolf, S.E.; Herndon, D.N. Influence of Fever on the Hypermetabolic Response in Burn-Injured Children. Arch. Surg. 2003, 138, 169-174. [CrossRef] [PubMed]

42. Rodriguez, N.; Jeschke, M.; Williams, F.; Kamolz, L.-P.; Herndon, D. Nutrition in Burns: Galveston Contributions. J. Parenter Enter. Nutr. 2011, 35, 704-714. [CrossRef]

43. Chang, D.W.; DeSanti, L.; Demling, R.H. Anticatabolic and anabolic strategies in critical illness: A review of current treatment modalities. Shock 1998, 10, 155-160. [CrossRef] [PubMed]

44. Jeschke, M.G.; Shahrokhi, S.; Hall, K.L. Enteral Nutrition Support in Burn Care: A Review of Current Recommendations as In-stituted in the Ross Tilley Burn Centre. Nutrients 2012, 4, 1554-1565.

45. Jeschke, M.G. Clinical review: Glucose control in severely burned patients-Current best practice. Crit. Care 2013, 17, 232. [CrossRef] [PubMed]

46. Gore, D.C.; Chinkes, D.; Heggers, J.; Herndon, D.N.; Wolf, S.E.; Desai, M. Association of Hyperglycemia with Increased Mortality after Severe Burn Injury. J. Trauma Inj. Infect. Crit. Care 2001, 51, 540-544. [CrossRef]

47. Jeschke, M.G.; Kulp, G.A.; Kraft, R.; Finnerty, C.C.; Mlcak, R.; Lee, J.O.; Herndon, D.N. Intensive insulin therapy in severely burned pediatric patients: A prospective random-ized trial. Am. J. Respir. Crit. Care Med. 2010, 182, 351-359. [CrossRef] [PubMed]

48. Van den Berghe, G.; Wilmer, A.; Hermans, G.; Meersseman, W.; Wouters, P.J.; Milants, I.; Van Wijngaerden, E.; Bobbaers, H.; Bouillon, R. Intensive insulin therapy in the medical ICU. N. Engl. J. Med. 2006, 354, 449-461. [CrossRef] [PubMed]

49. Flores, O.; Stockton, K.; Roberts, J.A.; Muller, M.J.; Paratz, J.D. The efficacy and safety of adrenergic blockade after burn injury: A systematic review and meta-analysis. J. Trauma Acute Care Surg. 2016, 80, 146-155. [CrossRef]

50. Brooks, N.C.; Song, J.; Boehning, D.; Kraft, R.; Finnerty, C.C.; Herndon, D.N.; Jeschke, M.G. Propranolol Improves Impaired Hepatic Phosphatidylinositol 3-Kinase/Akt Signaling after Burn Injury. Mol. Med. 2012, 18, 707-711. [CrossRef]

51. Takala, J.; Ruokonen, E.; Webster, N.R.; Nielsen, M.S.; Zandstra, D.F.; Vundelinckx, G.; Hinds, C.J. Increased Mortality Associated with Growth Hormone Treatment in Critically Ill Adults. N. Engl. J. Med. 1999, 341, 785-792. [CrossRef] [PubMed]

52. Jeschke, M.G.; Finnerty, C.C.; Suman, O.E.; Kulp, G.; Mlcak, R.P.; Herndon, D.N. The Effect of Oxandrolone on the Endocrinologic, Inflammatory, and Hypermetabolic Responses during the Acute Phase Postburn. Ann. Surg. 2007, 246, 351-362. [CrossRef]

53. Klein, M.B.; Hayden, D.; Elson, C.; Nathens, A.B.; Gamelli, R.L.; Gibran, N.S.; Herndon, D.N.; Arnoldo, B.; Silver, G.; Schoenfeld, D.; et al. The Association Between Fluid Administration and Outcome Following Major Burn. Ann. Surg. 2007, 245, 622-628. [CrossRef]

54. Pruitt, B.A. Protection from excessive resuscitation: "Pushing the pendulum back". J. Trauma 2000, 49, 567-568. [CrossRef] [PubMed]

55. Saffle, J.I.L. The phenomenon of "fluid creep" in acute burn resuscitation. J. Burn Care Res. 2007, 28, 382-395. [CrossRef] [PubMed]

56. Cartotto, R.; Zhou, A. Fluid creep: The pendulum hasn't swung back yet! J. Burn Care Res. 2010, 31, 551-558. [CrossRef] [PubMed]

57. Friedrich, J.B.; Sullivan, S.R.; Engrav, L.H.; Round, K.A.; Blayney, C.B.; Carrougher, G.J.; Heimbach, D.M.; Honari, S.; Klein, M.B.; Gibran, N.S. Is supra-Baxter resuscitation in burn patients a new phenomenon? Burns 2004, 30, 464-466. [CrossRef]

58. Engrav, L.H.; Colescott, P.L.; Kemalyan, N.; Heimbach, D.M.; Gibran, N.S.; Solem, L.D.; Dimick, A.R.; Gamelli, R.L.; Lentz, C.W. A Biopsy of the Use of the Baxter Formula to Resuscitate Burns or Do We Do It Like Charlie Did It? J. Burn. Care Rehabil. 2000, 21, 91-95. [CrossRef]

59. Cartotto, R.C.; Innes, M.; Musgrave, M.A.; Gomez, M.; Cooper, A.B. How Well Does The Parkland Formula Estimate Actual Fluid Resuscitation Volumes? J. Burn. Care Rehabil. 2002, 23, 258-265. [CrossRef]

60. Cancio, L.C.; Chávez, S.; Alvarado-Ortega, M.; Barillo, D.J.; Walker, S.C.; McManus, A.T.; Goodwin, C.W. Predicting increased fluid requirements during the resuscitation of thermally injured patients. J. Trauma 2004, 56, 404-413. [CrossRef]

61. Ivy, M.E.; Atweh, N.A.; Palmer, J.; Possenti, P.P.; Pineau, M.; D'Aiuto, M. Intra-abdominal hypertension and abdominal compart-ment syndrome in burn patients. J. Trauma 2000, 49, 387-391. [CrossRef]

62. Sullivan, S.R.; Friedrich, J.B.; Engrav, L.H.; Round, K.A.; Heimbach, D.M.; Heckbert, S.R.; Carrougher, G.J.; Lezotte, D.C.; Wiechman, S.A.; Honari, S.; et al. “Opioid creep" is real and may be the cause of "fluid creep. Burns 2004, 30, 583-590. [CrossRef] [PubMed]

63. Pruitt, B.A.; Mason, A.D.; Moncrief, J.A. Hemodynamic changes in the early postburn patient: The influence of fluid administration and of a vasodilator (hydralazine). J. Trauma 1971, 11, 36-46. [CrossRef] 
64. O'Mara, M.S.; Slater, H.; Goldfarb, I.W.; Caushaj, P.F. A Prospective, Randomized Evaluation of Intra-abdominal Pressures with Crystalloid and Colloid Resuscitation in Burn Patients. J. Trauma Inj. Infect. Crit. Care 2005, 58, 1011-1018. [CrossRef]

65. Goodwin, C.W.; Dorethy, J.; Lam, V.; Pruitt, B.A. Randomized trial of efficacy of crystalloid and colloid resuscitation on hemo-dynamic response and lung water following thermal injury. Ann. Surg. 1983, 197, 520-531. [CrossRef]

66. Herndon, D.; Barrow, R.; Linares, H.; Rutan, R.; Prien, T.; Traber, L.D.; Traber, D. Inhalation injury in burned patients: Effects and treatment. Burns 1988, 14, 349-356. [CrossRef]

67. Dai, N.-T.; Chen, T.-M.; Cheng, T.-Y.; Chen, S.-L.; Chen, S.-G.; Chou, G.-H.; Chou, T.-D.; Wang, H.-J. The comparison of early fluid therapy in extensive flame burns between inhalation and noninhalation injuries. Burns 1998, 24, 671-675. [CrossRef]

68. Perel, P.; Roberts, I.; Ker, K. Colloids versus crystalloids for fluid resuscitation in critically ill patients. Cochrane Database Syst. Rev. 2013, CD000567. [CrossRef]

69. Laupland, K.B.; Fisman, D.N. Surviving Sepsis? Can. J. Infect. Dis. Med. Microbiol. 2011, 22, 129-131. [CrossRef] [PubMed]

70. Merchant, N.; Smith, K.; Jeschke, M.G. An Ounce of Prevention Saves Tons of Lives: Infection in Burns. Surg. Infect. 2015, 16, 380-387. [CrossRef]

71. Greenhalgh, D.G. Sepsis in the burn patient: A different problem than sepsis in the general population. Burn. Trauma 2017, 5, 23. [CrossRef] [PubMed]

72. Bone, R.C.; Balk, R.A.; Cerra, F.B.; Dellinger, R.P.; Fein, A.M.; Knaus, W.A.; Schein, R.M.; Sibbald, W.J. Definitions for sepsis and organ failure and guidelines for the use of innovative therapies in sepsis. Chest 1992, 101, 1644-1655. [CrossRef]

73. Singer, M.; Deutschman, C.S.; Seymour, C.W.; Shankar-Hari, M.; Annane, D.; Bauer, M.; Bellomo, R.; Bernard, G.R.; Chiche, J.-D.; Coopersmith, C.M.; et al. The Third International Consensus Definitions for Sepsis and Septic Shock (Sepsis-3). JAMA 2016, 315, 801-810. [CrossRef]

74. Shankar-Hari, M.; Phillips, G.S.; Levy, M.L.; Seymour, C.W.; Liu, V.X.; Deutschman, C.S.; Angus, D.C.; Rubenfeld, G.D.; Singer, M. Developing a New Definition and Assessing New Clinical Criteria for Septic Shock: For the Third International Consensus Definitions for Sepsis and Septic Shock (Sepsis-3). JAMA 2016, 315, 775-787. [CrossRef] [PubMed]

75. Seymour, C.W.; Liu, V.X.; Iwashyna, T.J.; Brunkhorst, F.M.; Rea, T.D.; Scherag, A.; Rubenfeld, G.; Kahn, J.M.; Shankar-Hari, M.; Singer, M.; et al. Assessment of Clinical Criteria for Sepsis: For the Third International Consensus Definitions for Sepsis and Septic Shock (Sepsis-3). JAMA 2016, 315, 762-774. [CrossRef] [PubMed]

76. Greenhalgh, D.G.; Saffle, J.R.; Holmes, J.H.; Gamelli, R.L.; Palmieri, T.L.; Horton, J.W.; Tompkins, R.G.; Traber, D.L.; Mozingo, D.W.; Deitch, E.A.; et al. American Burn Association Consensus Conference to Define Sepsis and Infection in Burns. J. Burn Care Res. 2007, 28, 776-790. [CrossRef] [PubMed]

77. Chipp, E.; Milner, C.S.; Blackburn, A.V. Sepsis in burns: A review of current practice and future therapies. Ann. Plast. Surg. 2010, 65, 228-236. [CrossRef]

78. Yan, J.; Hill, W.F.; Rehou, S.; Pinto, R.; Shahrokhi, S.; Jeschke, M.G. Sepsis criteria versus clinical diagnosis of sepsis in burn pa-tients: A validation of current sepsis scores. Surgery 2018, 164, 1241-1245. [CrossRef]

79. Rech, M.A.; Mosier, M.J.; Zelisko, S.; Netzer, G.; Kovacs, E.J.; Afshar, M. Comparison of Automated Methods Versus the American Burn Association Sepsis Definition to Identify Sepsis and Sepsis With Organ Dysfunction/Septic Shock in Burn-Injured Adults. J. Burn Care Res. 2017, 38, 312-318. [CrossRef]

80. Yoon, J.; Kym, D.; Hur, J.; Kim, Y.; Yang, H.-T.; Yim, H.; Cho, Y.S.; Chun, W. Comparative Usefulness of Sepsis-3, Burn Sepsis, and Conventional Sepsis Criteria in Patients With Major Burns. Crit. Care Med. 2018, 46, e656-e662. [CrossRef]

81. Dellinger, R.P.; Carlet, J.M.; Masur, H.; Gerlach, H.; Calandra, T.; Cohen, J.; Gea-Banacloche, J.; Keh, D.; Marshall, J.C.; Parker, M.M.; et al. Surviving Sepsis Campaign guidelines for management of severe sepsis and septic shock. Crit. Care Med. 2004, 32, 858-873. [CrossRef]

82. Dellinger, R.P.; The Surviving Sepsis Campaign Guidelines Committee including The Pediatric Subgroup*; Levy, M.M.; Rhodes, A.; Annane, D.; Gerlach, H.; Opal, S.M.; Sevransky, J.E.; Sprung, C.L.; Douglas, I.S.; et al. Surviving Sepsis Campaign: International Guidelines for Management of Severe Sepsis and Septic Shock, 2012. Intensiv. Care Med. 2013, 39, 165-228. [CrossRef] [PubMed]

83. Rhodes, A.A.; Evans, L.E.; Alhazzani, W.; Levy, M.M.; Antonelli, M.; Ferrer, R.; Kumar, A.; Sevransky, J.E.; Sprung, C.L.; Nunnally, M.E.; et al. Surviving Sepsis Campaign: International Guidelines for Management of Sepsis and Septic Shock: 2016. Intensiv. Care Med. 2017, 43, 304-377. [CrossRef]

84. Kumar, A.; Roberts, D.; Wood, K.E.; Light, B.; Parrillo, J.E.; Sharma, S.; Suppes, R.; Feinstein, D.; Zanotti, S.; Taiberg, L.; et al. Duration of hypotension before initiation of effective antimicrobial therapy is the critical determinant of survival in human septic shock*. Crit. Care Med. 2006, 34, 1589-1596. [CrossRef]

85. László, I.; Trásy, D.; Molnár, Z.; Fazakas, J. Sepsis: From Pathophysiology to Individualized Patient Care. J. Immunol. Res. 2015, 2015, 1-13. [CrossRef]

86. von Heimburg, D.; Stieghorst, W.; Khorram-Sefat, R.; Pallua, N. Procalcitonin-A sepsis parameter in severe burn injuries. Burns 1998, 24, 745-750. [CrossRef]

87. Bargues, L.; Chancerelle, Y.; Catineau, J.; Jault, P.; Carsin, H. Evaluation of serum procalcitonin concentration in the ICU follow-ing severe burn. Burns 2007, 33, 860-864. [CrossRef] [PubMed]

88. Cabral, L.; Afreixo, V.; Meireles, R.; Vaz, M.; Marques, M.; Tourais, I.; Chaves, C.; Almeida, L.; Paiva, J.A. Procalcitonin kinetics after burn injury and burn surgery in septic and non-septic patients-A retrospective observational study. BMC Anesthesiol. 2018, 18, 1-10. [CrossRef] 
89. Cabral, L.; Afreixo, V.; Meireles, R.; Vaz, M.; Chaves, C.; Caetano, M.; Almeida, L.; Paiva, J.A. Checking procalcitonin suitability for prognosis and antimicrobial therapy monitor-ing in burn patients. Burns Trauma 2018, 6, 10. [CrossRef]

90. Cabral, L.; Afreixo, V.; Santos, F.; Almeida, L.; Paiva, J.A. Procalcitonin for the early diagnosis of sepsis in burn patients: A retro-spective study. Burns 2017, 43, 1427-1434. [CrossRef]

91. Germain, L.; Laval, L.C.D.Q.-U.; Larouche, D.; Nedelec, B.; Perreault, I.; Duranceau, L.; Bortoluzzi, P.; Cloutier, C.B.; Genest, H.; Caouette-Laberge, L.; et al. Autologous bilayered self-assembled skin substitutes (SASSs) as permanent grafts: A case series of 14 severely burned patients indicating clinical effectiveness. Eur. Cells Mater. 2018, 36, 128-141. [CrossRef]

92. Kumar, P. Classification of skin substitutes. Burns 2008, 34, 148-149. [CrossRef]

93. Paggiaro, A.O.; Bastianelli, R.; Carvalho, V.F.; Isaac, C.; Gemperli, R. Is allograft skin, the gold-standard for burn skin substitute? A systematic literature review and meta-analysis. J. Plast. Reconstr. Aesthetic Surg. 2019, 72, 1245-1253. [CrossRef]

94. Saffle, J.R. Closure of the excised burn wound: Temporary skin substitutes. Clin. Plast. Surg. 2009, 36, 627-641. [CrossRef] [PubMed]

95. Ter Horst, B.; Chouhan, G.; Moiemen, N.S.; Grover, L.M. Advances in keratinocyte delivery in burn wound care. Adv. Drug Deliv. Rev. 2018, 123, 18-32. [CrossRef]

96. O'Connor, N.; Mulliken, J.; Banks-Schlegel, S.; Kehinde, O.; Green, H. Grafting of burns with cultured epithelium prepared from autologous epidermal cells. Lancet 1981, 317, 75-78. [CrossRef]

97. Wood, F.; Kolybaba, M.; Allen, P. The use of cultured epithelial autograft in the treatment of major burn wounds: Eleven years of clinical experience. Burns 2006, 32, 538-544. [CrossRef] [PubMed]

98. Beaudoin Cloutier, C.; Goyer, B.; Perron, C.; Guignard, R.; Larouche, D.; Moulin, V.J.; Germain, L.; Gauvin, R.; Auger, F.A. In Vivo Evaluation and Imaging of a Bilayered Self-Assembled Skin Substitute Using a Decellularized Dermal Matrix Grafted on Mice. Tissue Eng. Part A 2017, 23, 313-322. [CrossRef]

99. Larson, K.W.; Austin, C.L.; Thompson, S.J. Treatment of a Full-Thickness Burn Injury with NovoSorb Biodegradable Temporiz-ing Matrix and RECELL Autologous Skin Cell Suspension: A Case Series. J. Burn Care Res. 2020, 41, 215-219. [CrossRef]

100. Greenwood, J.E.; Dearman, B.L. Comparison of a Sealed, Polymer Foam Biodegradable Temporizing Matrix against Integra ${ }^{\circledR}$ Dermal Regeneration Template in a Porcine Wound Model. J. Burn Care Res. 2012, 33, 163-173. [CrossRef] [PubMed]

101. Farroha, A.; Frew, Q.; El-Muttardi, N.; Philp, B.; Dziewulski, P. The use of Biobrane ${ }^{\circledR}$ to dress split-thickness skin graft in paedi-atric burns. Ann. Burns Fire Disasters 2013, 26, 94-97. [PubMed]

102. Whitaker, I.S.; Prowse, S.; Potokar, T.S. A critical evaluation of the use of Biobrane as a biologic skin substitute: A versatile tool for the plastic and reconstructive surgeon. Ann. Plast. Surg. 2008, 60, 333-337. [CrossRef]

103. Rogers, A.D.; Blackport, E.; Cartotto, R. The use of Biobrane ${ }^{\circledR}$ for wound coverage in Stevens-Johnson Syndrome and Toxic Epidermal Necrolysis. Burns 2017, 43, 1464-1472. [CrossRef]

104. Hunt, J.A.; Moisidis, E.; Haertsch, P. Initial experience of Integra in the treatment of post-burn anterior cervical neck contrac-ture. Br. J. Plast. Surg. 2000, 53, 652-658. [CrossRef] [PubMed]

105. Hicks, K.E.; Huynh, M.N.; Jeschke, M.; Malic, C. Dermal regenerative matrix use in burn patients: A systematic review. J. Plast. Reconstr. Aesthetic Surg. 2019, 72, 1741-1751. [CrossRef]

106. Li, A.; Dearman, B.L.; Crompton, K.E.; Moore, T.G.; Greenwood, J.E. Evaluation of a novel biodegradable polymer for the genera-tion of a dermal matrix. J Burn. Care Res. 2009, 30, 717-728. [CrossRef] [PubMed]

107. Wagstaff, M.J.; Salna, I.M.; Caplash, Y.; Greenwood, J.E. Biodegradable Temporising Matrix (BTM) for the reconstruction of defects following serial debridement for necrotising fasciitis: A case series. Burn. Open 2019, 3, 12-30. [CrossRef]

108. Issler-Fisher, A.C.; Fisher, O.M.; Haertsch, P.; Li, Z.; Maitz, P.K. Ablative fractional resurfacing with laser-facilitated steroid delivery for burn scar management: Does the depth of laser penetration matter? Lasers Surg. Med. 2019, 52, 149-158. [CrossRef]

109. Issler-Fisher, A.C.; Fisher, O.M.; Smialkowski, A.O.; Li, F.; van Schalkwyk, C.P.; Haertsch, P.; Maitz, P.K. Ablative fractional CO 2 laser for burn scar reconstruction: An exten-sive subjective and objective short-term outcome analysis of a prospective treatment cohort. Burns 2017, 43, 573-582. [CrossRef] [PubMed]

110. Hultman, C.S.; Friedstat, J.S.; Edkins, R.E.; Cairns, B.A.; Meyer, A.A. Laser resurfacing and remodeling of hypertrophic burn scars: The results of a large, prospective, before-after cohort study, with long-term follow-up. Ann. Surg. 2014, 260, 519-529. [PubMed]

111. Hultman, C.S.; Edkins, R.E.; Lee, C.N.; Calvert, C.T.; Cairns, B.A. Shine on: Review of Laser- and Light-Based Therapies for the Treatment of Burn Scars. Dermatol. Res. Pract. 2012, 2012, 1-9. [CrossRef] [PubMed]

112. Taudorf, E.H.; Danielsen, P.L.; Paulsen, I.F.; Togsverd-Bo, K.; Dierickx, C.; Paasch, U.; Haedersdal, M. Non-ablative fractional laser provides long-term improvement of mature burn scars-A randomized controlled trial with histological assessment. Lasers Surg. Med. 2015, 47, 141-147. [CrossRef]

113. Esselman, P.C.; Thombs, B.D.; Magyar-Russell, G.; Fauerbach, J.A. Burn rehabilitation: State of the science. Am. J. Phys. Med. Rehabil. 2006, 85, 383-413. [CrossRef] [PubMed]

114. Willows, B.M.; Ilyas, M.; Sharma, A. Laser in the management of burn scars. Burns 2017, 43, 1379-1389. [CrossRef]

115. Lee, S.J.; Yeo, I.K.; Kang, J.M.; Chung, W.S.; Kim, Y.K.; Kim, B.J.; Park, K.Y. Treatment of hypertrophic burn scars by combination laser-cision and pinhole method us-ing a carbon dioxide laser. Lasers Surg. Med. 2014, 46, 380-384. [CrossRef] [PubMed]

116. Alster, T.S.; Nanni, C.A. Pulsed Dye Laser Treatment of Hypertrophic Burn Scars. Plast. Reconstr. Surg. 1998, 102, $2190-2195$. [CrossRef] 
117. Donelan, M.B.; Parrett, B.M.; Sheridan, R.L. Pulsed dye laser therapy and z-plasty for facial burn scars: The alternative to exci-sion. Ann. Plast. Surg. 2008, 60, 480-486. [CrossRef] [PubMed]

118. Kawecki, M.; Bernad-Wiśniewska, T.; Sakiel, S.; Nowak, M.; Andriessen, A. Laser in the treatment of hypertrophic burn scars. Int. Wound J. 2008, 5, 87-97. [CrossRef] [PubMed]

119. Waibel, J.; Wulkan, A.J.; Lupo, M.; Beer, K.; Anderson, R.R. Treatment of burn scars with the 1550 nm nonablative fractional Erbium Laser. Lasers Surg. Med. 2012, 44, 441-446. [CrossRef] [PubMed]

120. Geomelas, M.; Ghods, M.; Ring, A.; Ottomann, C. “The Maestro": A Pioneering Plastic Surgeon—Sir Archibald McIndoe and His Innovating Work on Patients With Burn Injury During World War II. J. Burn Care Res. 2011, 32, 363-368. [CrossRef]

121. Faber, A.W.; Klasen, H.J.; Sauer, E.W.; Vuister, F.M. Psychological and social problems in burn patients after discharge. Scand. J. Plast. Reconstr. Surg. 1987, 21, 307-309. [CrossRef]

122. Fauerbach, J.A.; McKibben, J.; Bienvenu, O.J.; Magyar-Russell, G.; Smith, M.T.; Holavanahalli, R.; Patterson, D.R.; Wiechman, S.A.; Blakeney, P.; Lezotte, D. Psychological Distress After Major Burn Injury. Psychosom. Med. 2007, 69, 473-482. [CrossRef] [PubMed]

123. Cleary, M.; Visentin, D.C.; West, S.; Kornhaber, R. The importance of mental health considerations for critical care burns patients J. Adv. Nurs. 2018, 74, 1233-1235. [CrossRef]

124. Logsetty, S.; Shamlou, A.; Gawaziuk, J.P.; March, J.; Doupe, M.; Chateau, D.; Hoppensack, M.; Khan, S.; Medved, M.; Leslie, W.D.; et al. Mental health outcomes of burn: A longitudinal population-based study of adults hospitalized for burns. Burns 2016, 42, 738-744. [CrossRef]

125. Öster, C.; Sveen, J. The psychiatric sequelae of burn injury. Gen. Hosp. Psychiatry 2014, 36, 516-522. [CrossRef] [PubMed]

126. Holmes, W.J.; Hold, P.; James, M.I. The increasing trend in alcohol-related burns: It's impact on a tertiary burn centre. Burns 2010, 36, 938-943. [CrossRef]

127. McKibben, J.B.A.; Ekselius, L.; Girasek, D.C.; Gould, N.F.; Holzer, C.; Rosenberg, M.; Dissanaike, S.; Gielen, A.C. Epidemiology of burn injuries II: Psychiatric and behavioural perspectives. Int. Rev. Psychiatry 2009, 21, 512-521. [CrossRef] [PubMed]

128. Dyster-Aas, J.; Willebrand, M.; Wikehult, B.; Gerdin, B.; Ekselius, L. Major depression and posttraumatic stress disorder symp-toms following severe burn injury in relation to lifetime psychiatric morbidity. J. Trauma 2008, 64, 1349-1356.

129. Low, A.J.; Dyster-Aas, J.; Willebrand, M.; Ekselius, L.; Gerdin, B. Psychiatric morbidity predicts perceived burn-specific health 1 year after a burn. Gen. Hosp. Psychiatry 2012, 34, 146-152. [CrossRef] [PubMed]

130. Davydow, D.S.; Katon, W.J.; Zatzick, U.F. Psychiatric morbidity and functional impairments in survivors of burns, traumatic injuries, and ICU stays for other critical illnesses: A review of the literature. Int. Rev. Psychiatry 2009, 21, 531-538. [CrossRef] [PubMed]

131. Van der Does, A.J.; Hinderink, E.M.; Vloemans, A.F.; Spinhoven, P. Burn injuries, psychiatric disorders and length of hospitalization. J. Psychosom. Res. 1997, 43, 431-435. [CrossRef]

132. Tarrier, N.; Gregg, L.; Edwards, J.; Dunn, K. The influence of pre-existing psychiatric illness on recovery in burn injury patients: The impact of psychosis and depression. Burns 2005, 31, 45-49. [CrossRef] [PubMed]

133. Difede, J.; Barocas, D. Acute intrusive and avoidant PTSD symptoms as predictors of chronic PTSD following burn injury. J. Trauma Stress 1999, 12, 363-369. [CrossRef] [PubMed]

134. Corry, N.H.; Klick, B.; Fauerbach, J.A. Posttraumatic Stress Disorder and Pain Impact Functioning and Disability after Major Burn Injury. J. Burn Care Res. 2010, 31, 13-25. [CrossRef]

135. Wiechman Askay, S.; Patterson, D.R. What are the psychiatric sequelae of burn pain? Curr. Pain Headache Rep. 2008, $12,94-97$. [CrossRef]

136. Costa, B.A.; Engrav, L.H.; Holavanahalli, R.; Lezotte, D.C.; Patterson, D.R.; Kowalske, K.J.; Esselman, P.C. Impairment after burns: A two-center, prospective report. Burns 2003, 29, 671-675. [CrossRef]

137. Patterson, D.R.; Tininenko, J.; Ptacek, J.T. Pain during Burn Hospitalization Predicts Long-term Outcome. J. Burn Care Res. 2006, 27, 719-726. [CrossRef]

138. Malenfant, A.; Forget, R.; Papillon, J.; Amsel, R.; Frigon, J.-Y.; Choiniere, M. Prevalence and characteristics of chronic sensory problems in burn patients. Pain 1996, 67, 493-500. [CrossRef]

139. Dalal, P.K.; Saha, R.; Agarwal, M. Psychiatric aspects of burn. Indian J. Plast. Surg. 2010, 43, S136-S142. [CrossRef]

140. Romanowski, K.S.; Carson, J.; Pape, K.; Bernal, E.; Sharar, S.; Wiechman, S.; Carter, D.; Liu, Y.M.; Nitzschke, S.; Bhalla, P.; et al. American Burn Association Guidelines on the Management of Acute Pain in the Adult Burn Patient: A Review of the Literature, a Compilation of Expert Opinion, and Next Steps. J. Burn Care Res. 2020, 41, 1129-1151. [CrossRef]

141. Shakibaei, F.; Harandi, A.A.; Gholamrezaei, A.; Samoei, R.; Salehi, P. Hypnotherapy in Management of Pain and Reexperiencing of Trauma in Burn Patients. Int. J. Clin. Exp. Hypn. 2008, 56, 185-197. [CrossRef]

142. Patterson, D.R.; Questad, K.A.; De Lateur, B.J. Hypnotherapy as an Adjunct to Narcotic Analgesia for the Treatment of Pain for Burn Debridement. Am. J. Clin. Hypn. 1989, 31, 156-163. [CrossRef]

143. Patterson, D.R.; Everett, J.J.; Burns, G.L.; Marvin, J.A. Hypnosis for the treatment of burn pain. J. Consult. Clin. Psychol. 1992, 60, 713-717. [CrossRef] [PubMed]

144. Askay, S.W.; Patterson, D.R.; Jensen, M.P.; Sharar, S.R. A randomized controlled trial of hypnosis for burn wound care. Rehabil. Psychol. 2007, 52, 247-253. [CrossRef]

145. Morris, L.D.; Louw, Q.A.; Grimmer-Somers, K. The effectiveness of virtual reality on reducing pain and anxiety in burn injury patients: A systematic review. Clin. J. Pain 2009, 25, 815-826. [CrossRef] [PubMed] 
146. Arane, K.; Behboudi, A.; Goldman, R.D. Virtual reality for pain and anxiety management in children. Can. Fam. Physician Med. Fam. Can. 2017, 63, 932-934.

147. Hoffman, H.G.; Rodriguez, R.A.; Gonzalez, M.; Bernardy, M.; Peña, R.; Beck, W.; Patterson, D.R.; Meyer, W.J. Immersive Virtual Reality as an Adjunctive Non-opioid Analgesic for Pre-dominantly Latin American Children With Large Severe Burn Wounds During Burn Wound Cleaning in the Intensive Care Unit: A Pilot Study. Front. Hum. Neurosci. 2019, 13, 262. [CrossRef] [PubMed]

148. Hoffman, H.G.; Patterson, D.R.; Seibel, E.; Soltani, M.; Jewett-Leahy, L.; Sharar, S.R. Virtual reality pain control during burn wound debridement in the hydrotank. Clin. J. Pain 2008, 24, 299-304. [CrossRef]

149. Hoffman, H.G.; Doctor, J.N.; Patterson, D.R.; Carrougher, G.J.; Furness, T.A. Virtual reality as an adjunctive pain control during burn wound care in adolescent patients. Pain 2000, 85, 305-309. [CrossRef]

150. Ahmadpour, N.; Randall, H.; Choksi, H.; Gao, A.; Vaughan, C.; Poronnik, P. Virtual Reality interventions for acute and chronic pain management. Int. J. Biochem. Cell Biol. 2019, 114, 105568. [CrossRef]

151. Pourmand, A.; Davis, S.; Marchak, A.; Whiteside, T.; Sikka, N. Virtual Reality as a Clinical Tool for Pain Management. Curr. Pain Headache Rep. 2018, 22, 53. [CrossRef]

152. Eijlers, R.; Utens, E.M.; Staals, L.M.; de Nijs, P.F.; Berghmans, J.M.; Wijnen, R.M.; Hillegers, M.H.; Dierckx, B.; Legerstee, J.S. Systematic Review and Meta-analysis of Virtual Reality in Pediatrics: Effects on Pain and Anxiety. Anesth. Analg. 2019, 129, 1344-1353. [CrossRef]

153. Li, A.; Montaño, Z.; Chen, V.J.; I Gold, J. Virtual reality and pain management: Current trends and future directions. Pain Manag. 2011, 1, 147-157. [CrossRef] [PubMed]

154. Esselman, P.C.; Ptacek, J.T.; Kowalske, K.; Cromes, G.F.; DeLateur, B.J.; Engrav, L.H. Community Integration after Burn Injuries. J. Burn. Care Rehabil. 2001, 22, 221-227. [CrossRef]

155. Blakeney, P.; Partridge, J.; Rumsey, N. Community Integration. J. Burn Care Res. 2007, 28, 598-601. [CrossRef]

156. Quinn, T.; Wasiak, J.; Cleland, H. An examination of factors that affect return to work following burns: A systematic review of the literature. Burns 2010, 36, 1021-1026. [CrossRef] [PubMed]

157. Oster, C.; Kildal, M.; Ekselius, L. Return to work after burn injury: Burn-injured individuals' perception of barriers and facili-tators. J. Burn Care Res. 2010, 31, 540-550. [CrossRef]

158. Mackey, S.; Diba, R.; McKeown, D.; Wallace, C.G.; Booth, S.; Gilbert, P.; Dheansa, B. Return to work after burns: A qualitative research study. Burns 2009, 35, 338-342. [CrossRef] [PubMed]

159. Blakeney, P.; Meyer, W.; Robert, R.; Desai, M.; Wolf, S.; Herndon, D. Long-Term Psychosocial Adaptation of Children Who Survive Burns Involving 80\% or Greater Total Body Surface Area. J. Trauma Inj. Infect. Crit. Care 1998, 44, 625-634. [CrossRef]

160. Blakeney, P.; Meyer, W.; Moore, P.; Murphy, L.; Broemeling, L.; Robson, M.; Herndon, D. Psychosocial Sequelae of Pediatric Burns Involving 80\% or Greater Total Body Surface Area. J. Burn. Care Rehabil. 1993, 14, 684-689. [CrossRef] [PubMed]

161. Blakeney, P.; Thomas, C.; Holzer, C.; Rose, M.; Berniger, F.; Meyer, W.J. Efficacy of a Short-Term, Intensive Social Skills Training Program for Burned Adolescents. J. Burn. Care Rehabil. 2005, 26, 546-555. [CrossRef]

162. Meyer, W.J.; Blakeney, P.; Russell, W.; Thomas, C.; Robert, R.; Berniger, F.; Holzer, C. Psychological Problems Reported by Young Adults Who Were Burned as Children. J. Burn. Care Rehabil. 2004, 25, 98-106. [CrossRef]

163. Esselman, P.C. Burn Rehabilitation: An Overview. Arch. Phys. Med. Rehabil. 2007, 88, S3-S6. [CrossRef]

164. Richard, R.; Baryza, M.J.; Carr, J.A.; Dewey, W.S.; Dougherty, M.E.; Forbes-Duchart, L.; Franzen, B.J.; Healey, T.; Lester, M.E.; Li, S.K.; et al. Burn Rehabilitation and Research: Proceedings of a Consensus Summit. J. Burn Care Res. 2009, 30, 543-573. [CrossRef]

165. Moore, M.L.; Dewey, W.S.; Richard, R.L. Rehabilitation of the Burned Hand. Hand Clin. 2009, 25, 529-541. [CrossRef] [PubMed]

166. Richard, R.L.; Hedman, T.L.; Quick, C.D.; Barillo, D.J.; Cancio, L.C.; Renz, E.M.; Chapman, T.T.; Dewey, W.S.; Dougherty, M.E.; Esselman, P.C.; et al. A Clarion to Recommit and Reaffirm Burn Rehabilitation. J. Burn Care Res. 2008, 29, 425-432. [CrossRef]

167. Kottke, F.J.; Pauley, D.L.; Ptak, R.A. The rationale for prolonged stretching for correction of shortening of connective tissue. Arch. Phys. Med. Rehabil. 1966, 47, 345-352. [PubMed]

168. Larson, D.L.; Abston, S.; Evans, E.B.; Dobrkovský, M.; Linares, H.A. Techniques for decreasing scar formation and contractures in the burned patient. J. Trauma Inj. Infect. Crit. Care 1971, 11, 807-823. [CrossRef] [PubMed]

169. Baur, P.S.; Parks, D.H.; Larson, D.L. The Healing of Burn Wounds. Clin. Plast. Surg. 1977, 4, 389-407. [CrossRef]

170. Baur, P.S.; Larson, D.L.; Stacey, T.R.; Barratt, G.F.; Dobrkovský, M. Ultrastructural analysis of pressure-treated human hypertrophic scars. J. Trauma Inj. Infect. Crit. Care 1976, 16, 958-967. [CrossRef]

171. Linares, H.; Larson, D.; Willis-Galstaun, B. Historical notes on the use of pressure in the treatment of hypertrophic scars or keloids. Burns 1993, 19, 17-21. [CrossRef]

172. Van den Kerckhove, E.; Stappaerts, K.; Fieuws, S.; Laperre, J.; Massage, P.; Flour, M.; Boeckx, W. The assessment of erythema and thickness on burn related scars during pressure garment therapy as a preventive measure for hypertrophic scarring. Burns 2005, 31, 696-702. [CrossRef]

173. Perkins, K.; Davey, R.B.; Wallis, K. Current materials and techniques used in a burn scar management programme. Burns 1987, 13, 406-410. [CrossRef]

174. Staley, M.J.; Richard, R.L. Use of pressure to treat hypertrophic burn scars. Adv. Wound Care J. Prev. Health 1997, $10,44-46$.

175. Macintyre, L.; Baird, M. Pressure garments for use in the treatment of hypertrophic scars-a review of the problems associ-ated with their use. Burns 2006, 32, 10-15. [CrossRef] 
176. Mann, R.; Yeong, E.K.; Moore, M.; Colescott, D.; Engrav, L.H. Do Custom-Fitted Pressure Garments Provide Adequate Pressure? J. Burn. Care Rehabil. 1997, 18, 247-249. [CrossRef] [PubMed]

177. Cheng, J.; Evans, J.; Leung, K.; Clark, J.; Choy, T.; Leung, P. Pressure therapy in the treatment of post-burn hypertrophic scar-A critical look into its usefulness and fallacies by pressure monitoring. Burns 1984, 10, 154-163. [CrossRef]

178. Kealey, G.P.; Jensen, K.L.; Laubenthal, K.N.; Lewis, R.W. Prospective Randomized Comparison of Two Types of Pressure Therapy Garments. J. Burn. Care Rehabil. 1990, 11, 334-336. [CrossRef] [PubMed]

179. Palmieri, T.L.; Molitor, F.; Chan, G.; Phelan, E.; Shier, B.J.; Sen, S.; Greenhalgh, D.G. Long-Term Functional Outcomes in the Elderly After Burn Injury. J. Burn Care Res. 2012, 33, 497-503. [CrossRef] [PubMed]

180. Holavanahalli, R.K.; Helm, P.A.; Kowalske, K.J. Long-Term Outcomes in Patients Surviving Large Burns: The Musculoskeletal System. J. Burn Care Res. 2016, 37, 243-254. [CrossRef] [PubMed]

181. Wiechman, S.; Hoyt, M.A.; Patterson, D.R. Using a Biopsychosocial Model to Understand Long-Term Outcomes in Persons with Burn Injuries. Arch. Phys. Med. Rehabil. 2020, 101, S55-S62. [CrossRef] [PubMed]

182. Bakhtyar, T.S.N. Therapeutic Approaches to Combatting Hypermetabolism in Severe Burn Injuries. J. Intensiv. Crit. Care 2015, 1. [CrossRef]

183. American Burn Association. The Acute Burn ResUscitation Multicenter Prospective Trial (ABRUPT2). 2020. Available online: https: / / clinicaltrials.gov/ct2/show / NCT04356859 (accessed on 3 March 2021).

184. Datta, D.; Morris, A.C.; Antonelli, J.; Warner, N.; Brown, K.A.; Wright, J.; Simpson, A.J.; Rennie, J.; Hulme, G.; Lewis, S.M.; et al. Early PREdiction of Severe Sepsis (ExPRES-Sepsis) study: Protocol for an ob-servational derivation study to discover potential leucocyte cell surface biomarkers. BMJ Open 2016, 6, e011335. [CrossRef]

185. Hassanshahi, A.; Hassanshahi, M.; Khabbazi, S.; Hosseini-Khah, Z.; Peymanfar, Y.; Ghalamkari, S.; Su, Y.W.; Xian, C.J. Adiposederived stem cells for wound healing. J. Cell. Physiol. 2019, 234, 7903-7914. [CrossRef]

186. Kosaric, N.; Kiwanuka, H.; Gurtner, G.C. Stem cell therapies for wound healing. Expert Opin. Biol. Ther. 2019, 19, 575-585. [CrossRef] [PubMed]

187. Amini-Nik, S.; Dolp, R.; Eylert, G.; Datu, A.-K.; Parousis, A.; Blakeley, C.; Jeschke, M.G. Stem cells derived from burned skin-The future of burn care. EBioMedicine 2018, 37, 509-520. [CrossRef] [PubMed]

188. Martin-Piedra, M.Á.; Alfonso-Rodríguez, C.A.; Zapater Latorre, A.; Durand-Herrera, D.; Chato-Astrain, J.; Campos, F.; Sánchez Quevedo, M.d.C.; Alaminos Mingorance, M.; Garzón Bello, I.J. Effective use of mesenchymal stem cells in human skin sub-stitutes generated by tissue engineering. Eur. Cell Mater. 2019, 37, 233-249. [CrossRef] [PubMed] 